\title{
Research on Apparent Friction Factor in Perforated and Slotted Horizontal Filters to Dewater Opencast Mines Using Numerical Analysis
}

\author{
Tran Duc HUAN ${ }^{1, *)}$, Pham Duc THIEN ${ }^{1)}$
}

${ }^{1)}$ Hanoi University of Mining and Geology, 18 Vien street, Hanoi, Vietnam; mail: tranduchuan@humg.edu.vn; phamducthien@humg.edu.vn

http://doi.org/10.29227/IM-2020-02-24

Submission date: 06-03-2020 | Review date: 22-09-2020

\section{Abstract}

In the mining industry, the horizontal wells have been using for dewatering purpose for several years. Due to unique characteristics, those horizontal filters are recommended to balance both the mechanical strength and hydraulic performance. Pressure drop along the horizontal well is one of the essential factors that affect the performance of a wellbore, the dewatering capacity as well. The pressure drop is caused due to four separate factors: wall friction, perforation roughness, inflow acceleration and mixing effects. In this publication, numerical analysis was implemented with different types of perforated and slotted pipes to investigate the effects of two later factors: inflow acceleration and the mixing effects. The simulated data using ANSYS 14.5 was analyzed using universal velocity distribution law in combination with the roughness function and influx flow. The results revealed that the apparent friction factor is a linear function of roughness friction factor and the total inflow rate ratio.

Keywords: apparent friction factor, perforation roughness, total inflow rate, horizontal filters, dewatering, opencast mines

\section{Introduction}

The horizontal directional drilling (HDD) technology has been recently experimented in the mining industry to dewater opencast mines (Eichler \& Drebenstedt, 2014) (Mansel, Drebenstedt, Jolas, \& Blankenburg, 2012). This technique is adapted from the petroleum industry and utility construction. To effectively and economically apply this new method of dewatering, it is recommended to use perforated or slotted pipes as filters during its installation (Tran \& Drebenstedt, 2014) (Tran \& Drebenstedt, 2015). Moreover, those filters have to fulfil both mechanical strength and hydraulic performance aspect. Regarding hydraulic performance, the pressure drop of flow along the horizontal filter plays an important role and significantly affects the productivity of the dewatering system. This paper addresses the first phase of the study on the pressure drop along with the horizontal filters without inflow through the wall: the effect of perforation roughness.

The influence of perforation roughness and inflow through the wall were studied quite thoroughly in the literature (Jiang, Sarica, Ozkan, \& Kelkar, 2001) (Su \& Gudmundsson, 1998) (Ze Su \& Gudmundsson, 1993) (Su \& Gudmundsson, 1994). However, these studies mostly varied the size, the phasing, and the density of circular perforations. This presented work focuses on the size, the geometry, and the perforated/slotted ratio of different filter pipes using the numerical analysis. Those pipes had a strong correlation between the perforated/ slotted rate, the size, and shape of cavities. In the simulated study, the pipes with an inner diameter of $50 \mathrm{~mm}$, the $4 \mathrm{~mm}$ wall thickness, and the $920 \mathrm{~mm}$ perforated/slotted length were used. The perforated/slotted ratio varied from $2 \%, 3 \%$ to $5 \%$. The shapes of cavities were circular, axially or perpendicularly rectangular-like slotted. The widths of cavities varied from $1.5 \mathrm{~mm}, 2 \mathrm{~mm}$ to $3 \mathrm{~mm}$. The Reynolds number ranged between 10,000 and 80,000 with the increment of 5,000. There was, especially, inflow through the perforations or slots.

\section{Background}

In the previous study (Thien \& Huan, 2018), the authors found out that the incorporated form of the universal velocity distribution law for perforated/slotted pipes is

$$
\sqrt{\frac{8}{\mathrm{f}_{\mathrm{RS}}}}=2.5 \ln \left(\frac{\mathrm{Re}}{2} \sqrt{\frac{\mathrm{f}_{\mathrm{RS}}}{8}}\right)+1.41-\frac{\Delta \mathrm{u}}{\mathrm{u}^{*}}
$$

Where:

$\mathrm{f}_{\mathrm{RS}}$ : roughness friction factor

Re: Reynolds number

$\Delta \mathrm{u} / \mathrm{u}^{*}$ : roughness function

Interestingly, by plotting the roughness function, which derived from simulated data based on Equation (1)versus Reynolds number, a linear correlation was found. Let Rf denote the roughness function. Therefore, the linear correlation between $\mathrm{R} \neg \mathrm{f}$ and $\mathrm{Re}$ is expressed as

$$
\mathrm{R}_{\mathrm{f}}=\frac{\Delta \mathrm{u}}{\mathrm{u}^{*}}=\mathrm{a}_{1} \mathrm{R}_{\mathrm{e}}+\mathrm{a}_{2}
$$

In the case of existing inflow through cavities, the apparent friction factor can be described as (Huan, 2017)

$$
\mathrm{f}_{\mathrm{t}}=\mathrm{f}_{\mathrm{RS}}+\psi \frac{\mathrm{Q}_{\text {cav }}}{\mathrm{Q}_{\text {in }}}
$$

Where:

$\mathrm{f}_{\mathrm{t}}$ : the apparent friction factor

$\psi$ : a function of the number of cavities, perforation density, perforation size and influx coefficient

Qcav: the total radial inflow rate $\left(\mathrm{m}^{3} / \mathrm{s}\right)$

Qin: the inlet flowrate $\left(\mathrm{m}^{3} / \mathrm{s}\right)$

Equation (3) has been used to analyze the simulated data. 


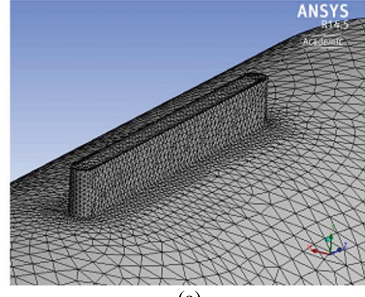

(a)

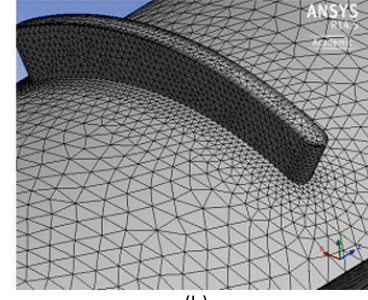

(b)

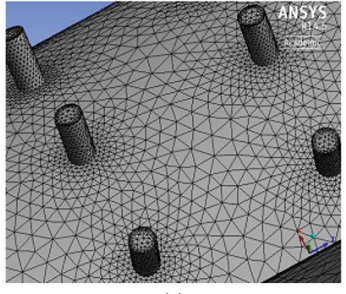

(c)

Fig. 1. Computational meshes of flows in pipes: (a). ASC pipe; (b). PSC pipe; (c). CPC pipe Rys. 1. Siatki obliczeniowe przepływów w rurach: (a). rura ASC; (b). rura PSC; (c). rura CPC

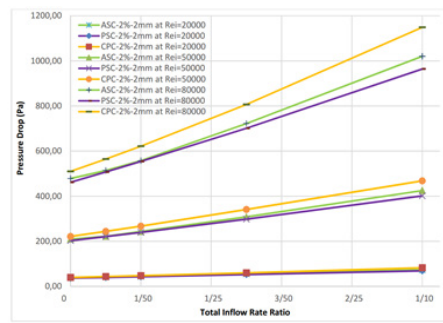

Fig. 2. Pressure Drop vs. Total Inflow Rate Ratio in pipes with $2 \%$ opening ratio, $2 \mathrm{~mm}$ size Rys. 2. Spadek ciśnienia a wskaźnik całkowitego natężenia przepływu w rurach ze wskaźnikiem otwarcia 2\%, rozmiar 2 mm

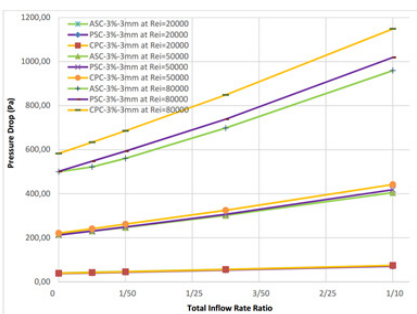

Fig. 3. Pressure Drop vs. Total Inflow Rate Ratio in pipes with $3 \%$ opening ratio, $3 \mathrm{~mm}$ size Rys. 3. Spadek ciśnienia a wskaźnik całkowitego natężenia przepływu w rurach o wskaźniku otwarcia 3\%, rozmiar 3 mm

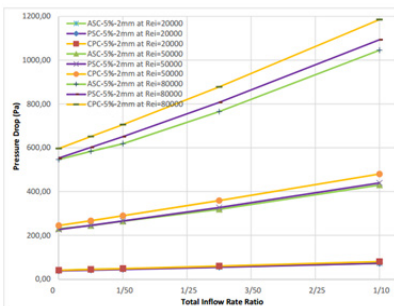

Fig. 4. Pressure Drop vs. Total Inflow Rate Ratio in pipes with 5\% opening ratio, $2 \mathrm{~mm}$ size Rys. 4. Spadek ciśnienia a wskaźnik całkowitego natężenia przepływu w rurach ASC o średnicy $2 \mathrm{~mm}$

\section{Simulation Setup and the Filter Pipes}

To calculate the pressure drop along the different perforated/slotted pipes, an academic finite volume code ANSYS Fluent 14.5 was employed. The numerical simulations used the SIMPLE, standard $\mathrm{k}-\varepsilon$ turbulent model, which was previously used and proved to have good agreement with experimental results (Abdulwahid, Dakhil, \& Injeti, 2013). The fluid was water, entered the pipes at 250 , with a constant density of, and the viscosity of. It was also assumed that the no-slip boundary condition along the isothermal walls. The inlet Reynolds number ranged from 10,000 to 80,000. The pipes were assumed hydraulically smooth on unperforated or non-slotted areas. Two initial conditions were taken into account: the mass flow at the inlet and the pressure at the outlet. In this work, the total inflow rate ratio changed from $1 / 100$ to $1 / 10$.
The pipes were uniformly perforated or slotted with different sizes, different shapes, and different ratios. In this work, the pipes with circular perforations are called Circular Perforated Cavity (CPC) pipes, the pipes with rectangular-like slots on the wall and along the pipe's axis are named Axial Slotted Cavity (ASC) pipes, and the pipes with rectangular-like slots on the wall and perpendicular to the pipe's axis are called Perpendicular Slotted Cavity (PSC) pipes. These pipes had 2, 3 and 5 percent of open ratio. The widths of cavities varied from $1.5 \mathrm{~mm}, 2 \mathrm{~mm}$ to $3 \mathrm{~mm}$. A total of 27 pipes were calculated.

The flows in pipes were discretized within ANSYS Meshing environment before solved by the Fluent solver. In the calculating process, symmetries were used to reduce computational time and resource. The computational meshes for different flows in pipes are shown in Figure 1. 


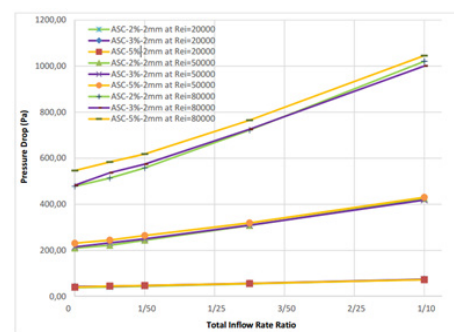

Fig. 5. Pressure Drop vs. Total Inflow Rate Ratio in ASC pipes with $2 \mathrm{~mm}$ size

Rys. 5. Spadek ciśnienia a wskaźnik całkowitego natężenia przepływu w rurach ASC o średnicy $2.0 \mathrm{~mm}$

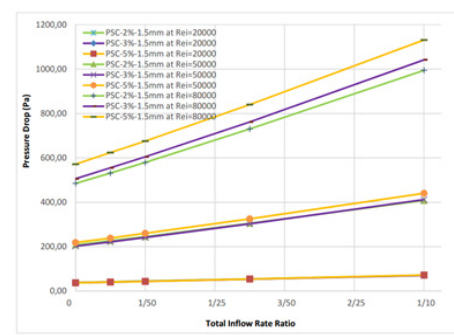

Fig. 6. Pressure Drop vs. Total Inflow Rate Ratio in PSC pipes with $1.5 \mathrm{~mm}$ size

Rys. 6. Spadek ciśnienia a wskaźnik całkowitego natężenia przepływu w rurach PSC o średnicy $1.5 \mathrm{~mm}$

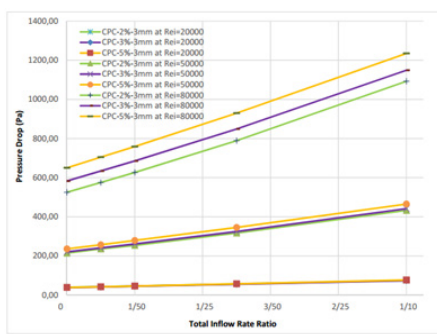

Fig. 7. Pressure Drop vs. Total Inflow Rate Ratio in PSC pipes with $3 \mathrm{~mm}$ size

Rys. 7: Spadek ciśnienia a wskaźnik całkowitego natężenia przepływu w rurach PSC z średnicą $3 \mathrm{~mm}$

\section{Results \\ 4.1 Effect of Cavity Shapes}

The simulated data showed that flows in pipes with different cavity shapes produced different pressure drops, particularly, when radial inflow through cavities exists. It can be seen in Figure 2, Figure 3 and Figure 4 that the pressure drops tend to increase when the total inflow rate ratio increases. The difference in pressure drop significantly showed when the Reynolds number is large. As Reynolds number at pipe inlet is small (i.e. 20,000), the variation of pressure drop between pipes with various cavity shapes is insignificant. However, the increasing trend of pressure drop still dominates.

The pressure drop in pipes at the low inlet Reynolds number at an inflow rate ratio of $1 / 10$ is about $200 \%$ bigger than when there is no inflow through cavities (i.e. inflow rate ratio of 0 ). As the pipe inlet velocity increased, the Reynolds number reached approximately 50,000, the difference in pressure drops more clearly showed. The CPC pipe tends to have the biggest pressure drop, while there is no significant difference in pressure drop between ASC and PSC pipes. The pressure drop at the inflow rate ratio of $1 / 10$ also showed approximately $200 \%$ bigger values in comparison with the pressure drop at zero inflow rate ratio.

When inlet Reynolds number is high (i.e. 80,000), the different pressure drop showed more clearly, especially, when the inflow rate ratio reached $1 / 10$. In this condition, the pressure drop in CPC pipes is the biggest one, and it shows a significant gap in comparison with ASC and PSC pipes. When the opening ratio is small (i.e. 2\%), the PSC pipe had a bigger pressure drop compared to the ASC pipe.

In contrast, when the opening ratio gets bigger (i.e. 3\% and $5 \%$ ), the ASC pipe showed a larger pressure drop. Moreover, at the upper inlet Reynolds number, the rate of increase of pressure drop is relatively similar to those values at the lower Reynolds numbers. At this high Reynolds number, when the inflow rate ratio gets $1 / 10$, the pressure drop also showed the about doubled value of those at zero inflow rate ratio.

\subsection{Effect of Perforation/Slot Ratio}

It was observed from Figure 5, Figure 6 and Figure 7 that with the same opening shape and the same opening size, the pressure drop created in pipes is larger when perforated and slotted densities are higher. It can be seen that the pressure drops in most pipes at a total inflow rate ratio of $1 / 10$ are approximately twice larger than those values at zero inflow rate ratio. In most pipes, the difference in pressure drop did no show clearly at low inlet Reynolds number (i.e. 20,000).

When the inlet Reynolds number reached higher value (i.e. 80,000), the distinction clearly showed up. For ASC pipes, the difference is modest. The biggest difference belongs to the 


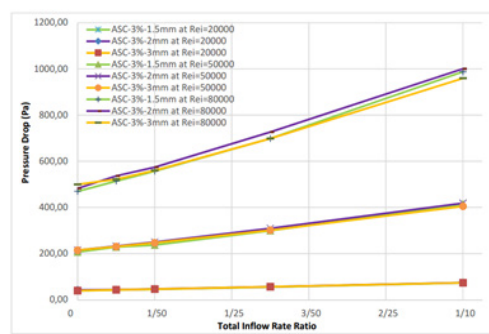

Fig. 8. Pressure Drop vs. Total Inflow Rate Ratio in ASC pipes with $3 \%$ cavity ratio

Rys. 8. Spadek ciśnienia a wskaźnik całkowitego natężenia przepływu w rurach ASC z 3\% wskaźnikiem otwarcia

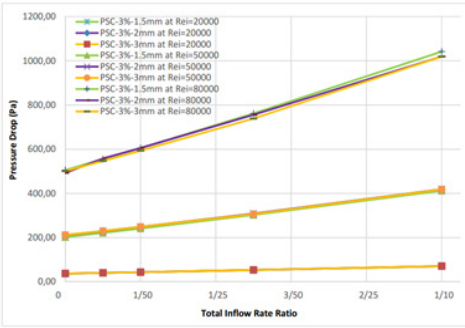

Fig. 9. Pressure Drop vs. Total Inflow Rate Ratio in PSC pipes with $3 \%$ cavity ratio

Rys. 9. Spadek ciśnienia a wskaźnik całkowitego natężenia przepływu w rurach PSC z 3\% wskaźnikiem otwarcia

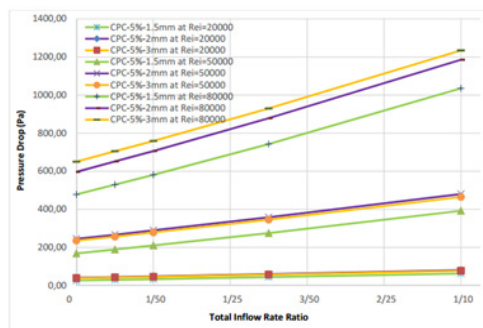

Fig. 10. Pressure Drop vs. Total Inflow Rate Ratio in CPC pipes with 5\% cavity ratio

Rys. 10. Spadek ciśnienia a wskaźnik całkowitego natężenia przepływu w rurach CPC z 5\% wskaźnikiem otwarcia

CPC pipes, particularly when the opening size is high. For the most pipes, the effect of cavity densities does not significantly show when the opening size is small (i.e. $1.5 \mathrm{~mm}$ size). In contrast, the distinction notably appears when opening width gets bigger value.

As a conclusion for the simulated data, which account for the effect of cavity ratios, it is not recommended to use the higher opening ratio to acquire the same inflow rate ratio due to the higher pressure drop.

\subsection{Effect of Perforation/Slot Size}

The observed data showed that with the same type of cavity and the equal opening ratio, the flows in pipes with different cavity sizes incurred different pressure drops. Figure 8 and Figure 9 indicated that ASC and PSC pipes produced small differences in pressure drops with various perforated and slotted sizes.

The differences did not significantly show with the full investigated range of Reynolds number, even with high Reynolds number (i.e. 80,000). In general, the pressure drop at $1 / 10$ total inflow rate ratio is two times bigger than that at zero inflow rate ratio. At the small opening ratio (i.e. 2\%), the difference in the size of the cavity did not show significant distinction in pressure drop. However, when the opening ratio gets higher value (i.e. 5\%), the pressure drop in ASC and PSC pipes showed a slight difference, and the bigger size, the larger pressure drop.

For the CPC pipes (Figure 10), the difference in pressure drop when cavity size changed are more clearly showed, especially when the inflow rate ratio is high. Figures revealed that the bigger cavity size, the bigger pressure drop CPC pipes introduced. These results indicated that it is not recommended to use a bigger cavity size for the same opening ratio to obtain the equal inflow rate ratio, particularly, for the CPC pipes.

\section{Data Analysis and Discussion}

The effect of radial inflow through cavities on the pipe wall can be analyzed by using the apparent friction factor, $\mathrm{ft}$, in Equation (3). Noticeably, the apparent friction factor, which expressed in Equation (3) indicates the linear correlation between the apparent friction factor and the total inflow rate ratio. Observing the pressure drop in correlation with the total inflow rate ratio from Figure 8, it is simply realized that there exists a linear correlation. This result makes the use of Equation (3) convincible.

The apparent friction factor is plotted against the total inflow rate ratio, as in Figure 11 and Figure 12. It can be observed from the figures, the friction factor when cavity inflow exists proportionally correlates with the inflow rate ratio. For the most pipes, when inlet Reynolds number changes, 


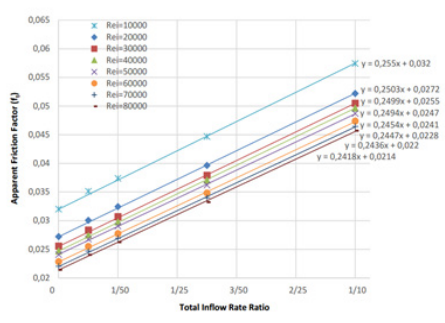

Fig. 9. Pressure Drop vs. Total Inflow Rate Ratio in PSC pipes with $3 \%$ cavity ratio

Rys. 9. Spadek ciśnienia a wskaźnik całkowitego natężenia przepływu w rurach PSC z 3\% wskaźnikiem otwarcia

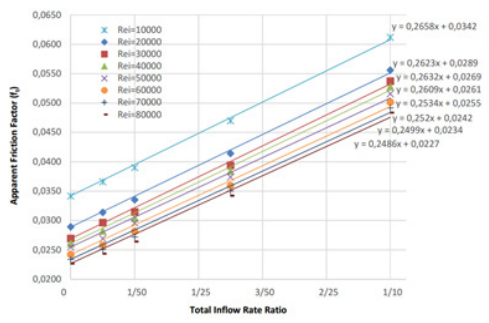

Fig. 11. Apparent Friction Factor vs. Total Inflow Rate Ratio in Pipe 2, ASC-2\%-2mm

Rys. 11. Widoczny współczynnik tarcia a wskaźnik całkowitego natężenia przepływu w rurze 2, ASC-2\% -2 mm

the increasing rate of the apparent friction factor is almost unchanged. Additionally, the linear function of the apparent friction factor and the total inflow rate is obtained. The data clearly show that the friction factor when there is no inflow is the determinant factor, that means the roughness friction factor plays a decisive role in the determination of the apparent friction factor.

For convenience, the equation of the apparent friction factor, which incorporates the roughness friction factor, the total inflow rate ratio, and other factors is re-expressed:

$f_{t}=f_{\text {RS }}+\psi \frac{Q_{\text {cav }}}{Q_{\text {in }}}$

where the roughness friction factor, fRS, is the friction factor corresponding to the no inflow case and have the implicit form as below

$$
\sqrt{\frac{8}{f_{\mathrm{RS}}}}=2.5 \ln \left(\frac{\mathrm{Re}}{2} \sqrt{\frac{\mathrm{fRS}_{\mathrm{RS}}}{8}}\right)+1.41-\frac{\Delta \mathrm{u}}{\mathrm{u}^{*}}
$$

Moreover, the roughness function, $\Delta \mathrm{u} / \mathrm{u}^{*}$, is a linear function of inlet Reynolds number. In Equation (4), $\psi$ is a coefficient, which defines the increasing rate of the apparent friction factor corresponding to the increase of the total inflow rate ratio. In this work, this coefficient is called the apparent coefficient. By observing the data in Figure 13 and Figure 14, it is noticed that the apparent coefficient does not significantly change with the varying inlet Reynolds number.

The data of the apparent coefficients were plotted against the inlet Reynolds numbers, as in Figure 13, and Figure 14. The results indicated that the apparent coefficient for all the pipes are independent of the inlet Reynolds numbers, and an average value can be obtained for each corresponding pipe.

For each pipe, once the roughness friction factor, $\mathrm{f}_{\mathrm{RS}}$, and the apparent coefficient, $\psi$, are known, the apparent friction factor at any total inflow rate ratio can be easily determined. Importantly, the roughness friction factor (i.e. there is no inflow) plays a decisive role in the estimation of the apparent friction factor for the corresponding pipe.
As revealed in Section 4, the radial inflow which enters the pipe flow introduces a larger pressure drop in all the investigated pipes. This result is in line with other studies on the effect of lateral inflow on the pressure drop in good horizontal flow. The apparent friction factor correlation developed in this work is a linear function of the roughness friction factor and the total inflow rate ratio. In the model, the apparent friction factor is heavily affected by the friction factor when there is no flux through the cavities on the pipe wall. The correlation (4) then was firmly backed by the simulated data.

For more understanding of individual component, which makes up the total pressure drop, it is necessary to delve into the simulated data. The factors which contribute to the total pressure drop include acceleration pressure drop, $\Delta$ pacc., wall friction pressure drop, $\Delta \mathrm{pw}$, perforation roughness pressure drop, $\Delta$ pperf., and liquid mixing pressure drop, $\Delta$ pmix. For convenience, the perforation roughness pressure drop and the liquid mixing pressure drop are grouped together, which is defined as an additional pressure drop, $\Delta$ padd.

The equations to estimate the acceleration pressure drop, the wall friction pressure drop, and the additional pressure drop are Equation (6) and (7), respectively (Ze Su \& Gudmundsson, 1993).

$$
\begin{aligned}
\Delta p_{\text {acc. }} & =\sum_{n=1}^{N} \rho\left(\bar{u}_{n+1}^{2}-\bar{u}_{n}^{2}\right)=\rho\left(\bar{u}_{N+1}^{2}-\bar{u}_{1}^{2}\right) \\
\Delta p_{w} & =\sum_{i=1}^{N-1} \Delta p_{w i}=\sum_{i=1}^{N-1}\left(\rho \frac{f_{i}}{2} \frac{\Delta L_{i}}{D}-\frac{2}{D} u_{2 i}\right)
\end{aligned}
$$

The plotting of each component of the total pressure drop against the total inflow rate ratio for some example pipes is shown in Figure 15, and Figure 16. According to the data, it can be realized that the additional pressure drop has a tendency to reduce as the total inflow rate ratio increases.

With the same declining rate, the additional pressure drop might have negative values when radial inflow increases. Because cavities and fluid mixing cause the additional pressure drop, it can be confirmed that the pressure drop due to the 


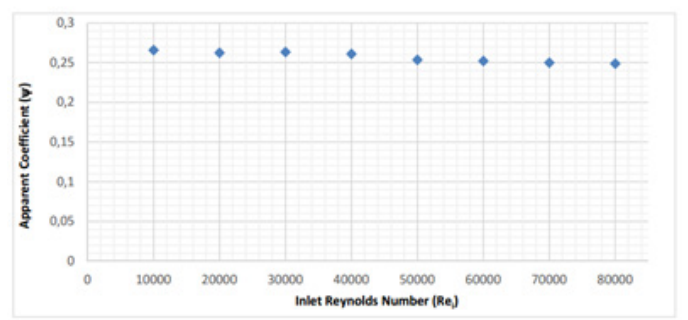

Fig. 13. Apparent Coefficient vs. Inlet Reynolds Number for ASC pipe-2\%-2mm Rys.13. Widoczny współczynnik a liczba wlotowa Reynoldsa dla rury ASC-2\% -2 mm

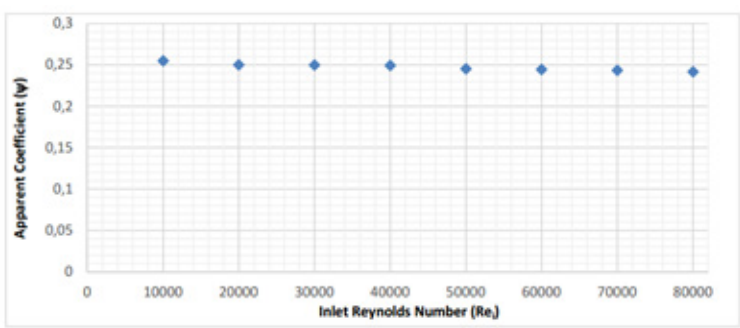

Fig 14. Apparent Coefficient vs. Inlet Reynolds Number for PSC pipes-2\%-2mm Rys. 14. Widoczny współczynnik a liczba wlotowa Reynoldsa dla rur PSC-2\% -2 mm

wall friction is minimized by smoothing effect. This result consolidated the conclusion that the radial inflow actually lubricates the pipe flow made by $\mathrm{Ze} \mathrm{Su}$ et al. and Abdulwahid et al. However, when the radial inflow increases, the acceleration pressure drop will enlarge. It makes the total pressure drop has a growing tendency.

\section{Conclusion}

Numerical simulations have been performed to investigate the flow, particularly, the pressure drop behaviour in perforated and slotted pipes with inflow through cavities. The geometry, the opening ratio, and the size of cavities were varied. The rate of inflow rate through cavities over the main pipe inlet inflow rate ranged from $1 / 100$ to $1 / 10$. The inlet Reynolds number varied from 10,000 to 80,000 with an increment of 10,000 . The model was solved by the same CFD code of ANSYS Fluent 14.5 using the SIMPLE algorithm, second-order scheme, and STANDARD $\mathrm{k}-\varepsilon$ turbulent model. The simulated data showed that the shape of cavities had a significant impact on the pressure drop behaviour, in which the CPC pipes introduced greater pressure loss in comparison with ASC and PSC pipes. With the same cavity ratio and the equal cavity size, the CPC pipes produced an average of $15 \%$ larger pressure drop at high inlet Reynolds number compared to ASC and PSC pipes. At low inlet Reynolds number, the difference was not clearly significant. The size of cavities, as well as the cavity ratio, also had a remarkable influence on pressure behaviour. It is recommended that not to use the higher cavity ratio to obtain the same inflow rate ratio and not to use bigger cavity size for the same cavity ratio to get the equal inflow rate ratio, particularly, for the CPC pipes. The smoothing effect of fluid mixing and the effect of the individual component that makes up the total pressure drop were also discussed. The results were in good agreement with other studies and showed reasonable liability.

The pressure drop acquired from simulations were also analyzed to clarify the impact of the total inflow rate ratio. The apparent friction factor calculated from the total pressure drop was expressed by a linear function of the roughness friction factor (i.e. there is no inflow through the wall) and the total inflow rate ratio, as in Equation (3). The roughness friction factor as the intercept of the function had a decisive influence. Meanwhile, the slope of the function is named the apparent coefficient had a constant value for each investigated pipe. 


\title{
Literature - References
}

1. Abdulwahid, M., Dakhil, S., \& Injeti, N. (2013). Numerical Investigation of the Turbulent Flow Parameters Distribution in a Partly Perforated Horizontal Wellbore. Vol. 9(ISSN: 1857-7881), pp. 372-387.

2. Eichler, R., \& Drebenstedt, C. (2014). Innovative Dewatering Concepts for Open Cast Mines Using Horizontal Wells (HDD-Wells). Mine Planning and Equipment Selection, pp. 697-706.

3. Huan, T. D. (2017). Numerical Research on the Pressure Drop in Perforated and Slotted Pipes used as Horizontal Filter. Freiberg, Germany: TU Bergakademie Freiberg.

4. Jiang, W., Sarica, C., Ozkan, E., \& Kelkar, M. (2001). Investigation of the Effects of Completion Geometry on Single-Phase Liquid Flow Behavior in Horizontal Wells. Vol. 123, pp. 119-126.

5. Mansel, H., Drebenstedt, C., Jolas, P., \& Blankenburg, R. (2012). Dewatering of Opencast Mines using Horizontal Wells.

6. Su, Z., \& Gudmundsson, J. (1998). Perforation Inflow reduces Frictional Pressure Loss in Horizontal Wellbores. 19, pp. 223-232.

7. Su, Z., \& Gudmundsson, J. S. (1994). Pressure Drop in Perforated Pipes: Experiments and Analysis.

8. Thien, P. D., \& Huan, T. D. (2018). Numerical Analysis of Friction Factor in Perforated and Slotted Horizontal Filters used to dewater Opencast Mines. Earth Sciences and Natural Resources for Sustainable Development (ERSD). Hanoi, Vietnam: Hanoi University of Mining and Geology, Vietnam.

9. Tran, D. H., \& Drebenstedt, C. (2015). Considerable Aspects to Select Filter Wells for Dewatering. Scientific Reports on Resources Issues, pp. 199-204.

10. Tran, D., \& Drebenstedt, C. (2014). Challenges during Horizontal Directional Drilling (HDD) Wells Installation for Dewatering Opencast Mines. Scientific Reports on Resources Issues, pp. 135-145.

11. Ze Su, \& Gudmundsson, J. (1993). Friction Factor of Perforation Roughness in Pipes.

\begin{abstract}
Badania nad widocznym współczynnikiem tarcia w perforowanych i szczelinowych filtrach poziomych do odwadniania kopalń odkrywkowych przy użyciu analizy numerycznej

$W$ ostatnich latach, wprzemyśle wydobywczym studnie poziome są wykorzystywane do odwadniania. Ze względu na wyjątkowe właściwości te filtry poziome sa zalecane, aby zrównoważyć zarówno wytrzymałość mechaniczna, jak $i$ wydajność hydrauliczna. Spadek ciśnienia wzdłuż odwiertu poziomego jest jednym z podstawowych czynników wplywajacych na wydajność odwiertu, a także wydajność odwadniania. Spadek ciśnienia jest spowodowany czterema odrębnymi czynnikami: tarciem o ścianki, chropowatościa perforacji, przyspieszeniem dopływu i efektami mieszania. W niniejszej publikacji zaimplementowano analizę numeryczna różnych typów rur perforowanych i szczelinowych $w$ celu zbadania wplywu dwóch późniejszych czynników: przyspieszenia doplywu i efektu mieszania. Symulowane dane za pomoca oprogramowania ANSYS 14.5 zostaly przeanalizowane przy użciu uniwersalnego prawa rozkładu prędkości w połaczeniu z funkcją chropowatości i przepływem napływowym. Wyniki wykazały, że widoczny współczynnik tarcia jest liniowa funkcja wspótczynnika tarcia chropowatości i wspótczynnika całkowitego naplywu.
\end{abstract}

Słowa kluczowe: widoczny współczynnik tarcia, chropowatość perforacji, całkowity napływ, studnie poziome, odwadnianie, kopalnie odkrywkowe 